\title{
肝細胞癌の細胞所見と $\alpha$-フェトプロティン
}

一酵素抗体法の応用

\begin{abstract}
長崎大学医学部病理学第 1 教室 ${ }^{11}$, 同 附属病院検查部 ${ }^{2}$, 大分医科大学附属病院検査部 ${ }^{31}$ 松尾 武 ${ }^{1)}$ 柴田 正則 $^{12}$ 穴見 正信 ${ }^{2}$ 林田 㴦子 ${ }^{3)}$
\end{abstract}

われわれは肝細胞癌の細胞診における $\alpha$-Fetoprotein (AFP) の診断的意義につき検討した. 手 術または剖検された肝細胞癌 15 例, 肝硬変症 1 例, 重複併合奇形腫 1 例, 胎児肝 3 例の肝穿 刺物 を Peroxidase-anti-peroxidase-method (PAP 法)により AFP の細胞内局在を同一症例の組織標 本と対比し, さらに血清 AFP 值と肝細胞癌細胞 Grading の関係を調べた. 肝細胞癌例の AFP-PAP 法の成績は, 細胞・組織標本とも陰性が 3 例, 細胞標本のみ陰性が 1 例, 残りの 11 例は陽性であ った. 3 例の陰性例のうち， 2 例では血清 AFP 值が低く，1例は治療の目的で塞栓術が行われた のち, 腫瘍が摘出され, 腫瘍細胞は広範に壞死に宿っていた. 組織での Edmondson 分類に相当す る肝細胞癌の細胞 Grading を試みた結果, 組織 Grade と細胞 Grade はほぼ一致した. 血清 AFP と細胞 Grade の関係では, 細胞 Grade の高い例ほど血清 AFP 值も高值の傾向がみられた.

Key words : Liver — Immunoperoxidase technique-Alpha-fetoprotein-Hepatocellular carcinoma-Cytology

\section{はじめに}

近年, 診断法の進歩により肝癌の早期診断が容易にな ってきたが，確実な鑑別診断には組織診が必要である. また小口径針を用いる肝穿刺細胞診も有用なことが認め られ，広く行われているが1,3,4,6,8,11 13)，その診断の信 頼性になお一部不安があると感じる。そこでわれわれは 穿刺吸引法で得られた肝細胞癌細胞について, 腫瘍マー カーの $1 つ \alpha$-Fetoprotein (以下 AFP と略す) の産生能

Alpha-fetoprotein and cytological findings of hepatocellular carcinoma - Application of immunoperoxidase technique -

Takeshi MATSUO, M.D. and Masanori SHIBATA

1st Department of Pathology, Nagasaki University School of Medicine

Masanobu ANAMI, C.T., I.A.C.

Central Laboratory, Nagasaki University Hospital

Yoko HAYASHIDA, C.T., I.A.C.

Central Laboratory, Ooita Medical University Hospital 論文別刷請求先 ⿶852 長崎市坂本町 12 の 長崎大学医 学部第 1 病理 松尾 武

昭和 60 年 3 月 11 日受付

昭和 60 年 12 月 20 日受理
を調べ，腫瘍マーカーの細胞診への応用につき検討し た.

\section{材 料と方 法}

昭和 58 年 10 月から翌年 5 月までの間に，当院で手術 または剖検された肝細胞癌例を中心にした 22 例（表 1） を用いた，細胞標本は腫瘍または病変部が確実に採取で きるよう直視下に穿刺吸引し，あるい媇鮮割面より择 印しパパニコロー染色とギムザ染色を行った，組織標本 作製には抗原物質の消失を防ぐため融解温度 $54^{\circ} \mathrm{C}$ 以下 のパラフィンを使用した. AFP 酵素抗体染色法には米国 Immulok 社のヒストセットAFP を用い図 1 に示寸手順 で行った. AFP-PAP 法の成績は陽性細胞の局在分布の 量と呈色の濃度により (一)〜 (卅)に分けた. 血清 AFP 值は Radioimmunoassay（RIA）法により測定した. 肝 細胞癌の組織診の細胞異型度は, わが国の原発性肝癌取 扱い規約5) の分類に従った。一方細胞診の細胞異型度に ついては次のように Grade I から IV までを分類した。

Grade I : 腫場細胞は正常肝細胞に酷似し, わずかに 核の大小不同，クロマチン増量がみられ，小さな核小体 
表 1 材料と方法

\begin{tabular}{|c|c|}
\hline $\begin{array}{l}\text { 肝細胞癌 } \\
\quad \text { (手術例 } \\
\quad \text { (剖検例 }\end{array}$ & $\begin{array}{l}8) \\
7)\end{array}$ \\
\hline $\begin{array}{l}\text { 肝 硬 変 } \\
\text { 胎 児肝 } \\
\text { 正 常肝 } \\
\text { 重複併合奇形腫 }\end{array}$ & $\begin{array}{l}1 \text { 例 } \\
3 \text { 例 } \\
2 \text { 例 } \\
1 \text { 例 }\end{array}$ \\
\hline \multicolumn{2}{|c|}{$\begin{array}{c}\text { 細 胞………………穿刺吸引, 捺印標本 } \\
\text { 固 定: } 95 \% \text { エタノール・エーテル等量液 } \\
4 \% \text { パラホルムアルデヒド } \\
\text { 乾 燥 }\end{array}$} \\
\hline \multicolumn{2}{|c|}{$\begin{array}{l}\text { 組 織………………プラフィン包埋ブロック } \\
\text { 固 定: } 4 \% \text { パラホルムアルデヒド } \\
\text { 染 色 }\end{array}$} \\
\hline
\end{tabular}

\section{を認める(写真 1 ).}

Grade II : 腫瘍細胞の核は Grade I のものより一層大 きく, 大小不同もきわだっているが, 細胞は平面的に配 列し豊富な胞体を有している (写真 2 ).

Grade III : 腫瘍細胞の核, 核小体はともに大きく, ク ロマチンも増量し粗大顆粒状となり, 細胞質は少なく $\mathrm{N} / \mathrm{C}$ 比が大となる. 細胞の重積傾向もみられ, 異型性の 著しい巨核や多核細胞がみられる (写真 $3 ， 4$ ).

Grade IV : 腫瘍細胞の N/C 比はさらに大となり, 細 胞質は乏しく, 細胞相互の結合性も弱い（写真 5 ).

\section{成績}

\section{1. 症 例}

AFP-PAP 法を用い検索した 22 例中の代表例を提示 する.

\section{a) 5 カ月ヒト胎児肝}

組織, 細胞標本ともほぼすべての肝細胞は AFP 陽性 であった（写真 6 ).

\section{b) 肝細胞癌 (手術症例 1)}

63 歳, 男性. 入院時の血清 AFP 值は $2,361 \mathrm{ng} / \mathrm{ml}$. 塞栓術治療後, 血清 AFP 值は低下した. 手術時に腫瘍 は $5.5 \times 5.6 \mathrm{~cm}$ 大, 周囲肝組織に線維症がみられた。

組織所見 : 腫瘍の一部は偽腺管型を示すが, 大半は索 状型で Grade II carcinoma であった (写真 7 a).

細胞所見: 腫瘍細胞は広い泡沫状の胞体を有し, 核ク ロマチンは増量し, 軽度の核の大小不同がみられ, 核小 体も増大していた. 細胞 Grade II (写真 $8 \mathrm{a}$ ).

AFP-PAP 法所見 : 組織, 細胞標本とも陰性であった (写真 $7 \mathrm{~b}, 8 \mathrm{~b}$ ).

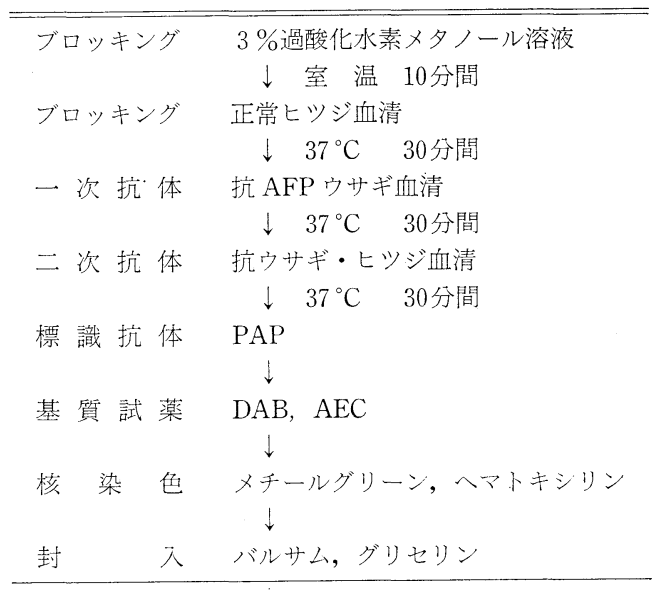

図 1 酵素抗体 PAP 法 (米国 Immulok 社ヒストセット AFP)

c) 肝細胞癌 (手術症例 3 )

56 歳, 男性. 昭和 55 年 3 月肝硬変と診断され, 翌年 4 月血清 $\mathrm{AFP} 81.8 \mathrm{ng} / \mathrm{m} l$ となり肝腫瘍を含む肝部分切 除が行われた. 昭和 57 年 10 月血清 $\mathrm{AFP} 2,885 \mathrm{ng} / \mathrm{m} l$ に 上昇したため第 2 回目の肝腫瘍切除術が行われた. 腫瘍 は $2.0 \times 1.8 \mathrm{~cm}$ 大で, 肉眼的に肝硬変を伴っていた.

組織所見 : 腫瘍は厚い索状型を示し Grade III carcinoma であった (写真 9 a).

細胞所見 : 腫瘍細胞の結合性は弱く, N/C 比は大. 核 は類円形で切れ込みがみられ, クロマチンは増量し, 増 大した核小体が目立った. 細胞 Grade IV (写真 10 a).

AFP-PAP 法所見 : 組織標本では半数ほどの腫瘍細胞 に陽性反応がみられた（写真 9 b). 細胞標本では，ほと んどすべての細胞が強い陽性反応を示した (写真 $10 \mathrm{~b}$ ).

d) 肝細胞癌 (手術症例 4)

62 歳, 男性. 肝シンチグラムで左葉に欠損像がみら れ, 血清 AFP 值は $10,420 \sim 7,581 \mathrm{ng} / \mathrm{m} l$ であった. 肝 左葉切除術が行われ, 腫瘍は $3.2 \times 3.7 \mathrm{~cm}$ 大で, ほかに 小娘結節もみられた.

組織所見 : 腫瘍は索状型, 一部充実型で Grade II carcinoma であった（写真 $11 \mathrm{a}$ ).

細胞所見 : 腫瘍細胞は結合性, 重積性を示し, N/C 比 は中等大. 核は長円形で不正がみられクロマチンは増量 し, 核小体は小さかった. 細胞 Grade III (写真 $12 \mathrm{a}$ ).

AFP-PAP 法所見 : 組織標本では大半の腫瘍細胞が陽 性反応を示した (写真 11 b). 細胞標本でも陽性反応がみ られた (写真 $12 \mathrm{~b}$ ).

e) 肝細胞癌 (剖検例 5 )

49 歳, 男性. 40 歳のとき肝硬変. 胸部X線検查で肺 転移性腫瘍を疑われて入院した. 血清 AFP 值は 283,588 
表 2 肝細胞癌手術例

\begin{tabular}{|c|c|c|c|c|c|c|c|c|}
\hline \multirow{2}{*}{ 例 } & \multirow{2}{*}{ 年齢 } & \multirow{2}{*}{ 性 } & \multirow{2}{*}{$\mathrm{AFP} \mathrm{ng} / \mathrm{m} l$} & \multicolumn{2}{|c|}{ 異型度 } & \multicolumn{2}{|c|}{ AFP 染色 } & \multirow{2}{*}{ 備考 } \\
\hline & & & & 組織* & 細胞 & 組織 & 細胞 & \\
\hline 1 & 63 & 男 & $\begin{array}{c}1,000 \sim 2,369 \\
(1,481)\end{array}$ & II & II & $(-)$ & $(-)$ & 塞栓術 \\
\hline 2 & 36 & 男 & $\begin{array}{c}42.4 \sim 139.5 \\
(139.5)\end{array}$ & II & II & $(-)$ & $(-)$ & \\
\hline 3 & 56 & 男 & $\begin{array}{c}2.1 \sim 2,855 \\
(2,855)\end{array}$ & III & IV & $(H)$ & (H) & 再手術 \\
\hline 4 & 62 & 男 & $\begin{array}{c}4,659 \sim 10,420 \\
(4,659)\end{array}$ & II & III & (H) & (H) & \\
\hline 5 & 73 & 女 & $\begin{array}{l}25 \sim 100,000 \\
\left(19,99^{\circ}\right)\end{array}$ & III & III & (H) & (H) & \\
\hline 6 & 35 & 女 & $\begin{array}{c}99.6 \sim 43,646 \\
(4,496)\end{array}$ & II & II & $(+t) \sim(+)$ & (H) & 再手術 \\
\hline 7 & 36 & 男 & $\begin{array}{c}11.8 \sim 446 \\
(446)\end{array}$ & II & II & (H) & $(+)$ & \\
\hline 8 & 72 & 男 & $\begin{array}{l}430 \sim 850 \\
\quad(640)\end{array}$ & II & III & (H) & $(+)$ & \\
\hline
\end{tabular}

*原発性肝癌取扱い規約)による

表 3 肝細胞癌剖検例

\begin{tabular}{|c|c|c|c|c|c|c|c|c|}
\hline \multirow{2}{*}{ 例 } & \multirow{2}{*}{ 年齢 } & \multirow{2}{*}{ 性 } & \multirow{2}{*}{ AFP $\mathrm{ng} / \mathrm{m} l$} & \multicolumn{2}{|c|}{ 異型度 } & \multicolumn{2}{|c|}{ AFP 染色 } & \multirow{2}{*}{ 備考 } \\
\hline & & & & 組織* & 細胞 & 組織 & 細胞 & \\
\hline 1 & 58 & 男 & $\begin{array}{l}4,845 \sim 23,430 \\
(23,430)\end{array}$ & III & IV & $(+)$ & $(-)$ & $\begin{array}{l}\text { 肝硬変 } \\
\text { 塞栓術 }\end{array}$ \\
\hline 2 & 57 & 男 & $\begin{array}{c}14,102 \sim 40,909 \\
(26,489)\end{array}$ & III & III & (H) & $(H)$ & $\begin{array}{l}\text { 肝硬変 } \\
\text { 塞栓術 }\end{array}$ \\
\hline 3 & 67 & 女 & $\begin{array}{c}1,660 \sim 27,689 \\
(2,881)\end{array}$ & III & III & $(+)$ & (H) & \\
\hline 4 & 70 & 女 & $\begin{array}{l}51,200 \sim 141,820 \\
(141,820)\end{array}$ & IV & $\mathrm{III} \sim \mathrm{IN}$ & $(+)$ & $(H)$ & 肝硬変 \\
\hline 5 & 49 & 男 & $\begin{array}{c}222,339 \sim 283,588 \\
(274,930)\end{array}$ & IV & $\mathrm{III} \sim \mathrm{IV}$ & (H) & $(H)$ & 肝硬変 \\
\hline 6 & 58 & 女 & $\begin{array}{l}2 \sim 336 \\
(336)\end{array}$ & III & III & $(+)$ & $(+)$ & $\begin{array}{l}\text { アルコール } \\
\text { 肝硬変 }\end{array}$ \\
\hline 7 & 55 & 男 & 0 & II & $\mathrm{I} \sim \mathrm{II}$ & $(-)$ & $(-)$ & $\begin{array}{l}\text { 輸 血 } \\
\text { 肝硬変 }\end{array}$ \\
\hline
\end{tabular}

*原発性肝癌取扱い規約

$\mathrm{ng} / \mathrm{m} l$ であった. 肝の Computed Tomography (CT) 検 查で肝中央部に $10 \times 10 \mathrm{~cm}$ 大の腫瘤を認めた. 1 力月 後, 腹腔内出血で死亡し, 剖検したところ, 乙型肝硬変 と肝中央の腫瘍があり，両肺と気管分岐部，肺門リンパ 節などに転移がみられた。

組織所見 : 腫瘍は厚い索状型から充実型を示し Grade IV carcinoma であった（写真 $13 \mathrm{a}$ ).

細胞所見 : 紡鍾形の腫瘍細胞が重畳性の細胞集塊をつ くり，一部に腺管構造もみられたが，集塊辺縁のふちど り感がなく, 細胞配列が不規則になっていた. 核クロマ チンは増量し，核小体も増大し $\mathrm{N} / \mathrm{C}$ 比は大きく細胞 Grade III〜IV であった（写真 14 a).

AFP-PAP 法所見 : 組織標本では腫瘍細胞の大半が陽
性反応を示した (写真 $13 \mathrm{~b}$ ). 細胞標本でも強い陽性反応 がみられた（写真 $14 \mathrm{~b}$ ).

2. 肝細胞癌例の組織診断, 細胞診断 および AFPPAP 法成績

肝細胞癌の手術例 8 例と剖検例 7 例の結果を表 2,3 に示した. 各症例の血清 AFP 值は経過中の最小值と最 大值を記し，括弧内の值は材料採取直前の值である. 血 清 AFP 值は, 剖検例 7 の 1 例を除いて全例が陽性 (20 $\mathrm{ng} / \mathrm{ml}$ 以上）であった。

細胞異型度を組織診と細胞診で比較すると 15 例中 11 例で一致した．不一致の例でも著しい差はなかった.

AFP-PAP 法で組織, 細胞標本ともに陰性の例が 3 例, 組織標本は陽性で細胞標本のみ陰性の例が 1 例あった 


\begin{tabular}{|c|c|c|c|c|}
\hline & 300 & $10^{3}$ & $10^{4}$ & $10^{5} \mathrm{AFPng} / \mathrm{ml}$ \\
\hline \multicolumn{5}{|l|}{ Grade I } \\
\hline Grade II & - 0 & - 0 & & \\
\hline Grade III & 00 & 00 & 00 & 0 \\
\hline Grade IV & & o & c & 0 \\
\hline
\end{tabular}

図 2 肝細胞癌の細胞 grading と血清 $\alpha$-フェト プロテイン值

が, 残りの 11 例では組織, 細胞標本ともに陽性であった。

\section{3. 細胞像 Grading 亡血清 AFP 值の関係}

各症例の細胞像 Grading と血清 AFP 值との関連を知 るためにグラフを描いた (図 2 ). 細胞像の異型度の高い 肝細胞癌例に血清 AFP 值が高い傾向がみられた。

\section{考案}

今回，われわれが検索した結果，肝細胞癌 15 例中 11 例で細胞標本の AFP-PAP 法は陽性反応を示した. それ らは組織標本の結果とも一致していた４例の陰性例の うち，3例では組織標本でも陰性であった．そのうち 1 例は, 血清 AFP 值が $0 \mathrm{ng} / \mathrm{m} l$ で非 AFP 産生癌と考え てもよく，1例は血清 AFP 值が $139.5 \mathrm{ng} / \mathrm{m} l$ で正常值 (20 ng/ml) を超えていた. AFP-PAP 法が陰性であった 原因としては, 今回行った AFP 酵素抗体法の方法に問 題点があり, 血清 AFP 值が $300 \mathrm{ng} / \mathrm{m} l$ 以下の低值の症 例では陽性結果が得られないように感じた。 また，ほか の 1 例では血清 AFP 值は $1,481 \mathrm{ng} / \mathrm{m} l$ の高值であった が, 治療の目的で塞栓術が行われ, 組織学的に腫瘍細胞 は変性に陥り, 血清 AFP 值も漸次下降しつつあったこ となどを考えると, 塞栓術が有効で細胞活性に影響を与 えたとも想像できる. しかし, 材料採取, 固定, 染色の 段階で何か問題があったかも知れない，これまでに細胞 診に酵素抗体法を導入するにあたり, 塗抹方法, 固定液 の種類, 検出法の比較, 消化法による特異免疫反応の増 強などに多くの注意が払われてきた ${ }^{2,7,8,9)}$. AFP に関し ては, エーテル・アルコール等量液固定より, パラホル ムアルデヒド固定標本の方が陽性細胞と背景のコントラ ストが明確と思われた. また組織, 細胞標本ともに細胞 すべてが同一の反応を示さずに一部の細胞のみが陽性で あったり, 反応の呈色の濃さに差がみられた. これは細 胞の AFP 産生能を表現しているや否やは不明である. 今回の AFP-PAP 法では蛋白分解酵素による消化など は一切行っていない.
次に細胞診 Grading とAFP-PAP 法成績との関連に は, とくに相関はみられなかった. 細胞診 Grading と 血清 AFP 值との関連を調べたところ, 細胞 Grade の高 い症例ほど血清 AFP 值も高いことが判明した.

今回の検索で, AFP-PAP 法は肝癌, とくに肝細胞癌 と転移性肝癌との鑑別, さらに肝細胞癌と胆管 細胞癌 (肝内胆管癌) の鑑別診断に有用な方法と考えられた.

\section{Summary}

Embryo-specific $\alpha$-fetoprotein (AFP) had been detected in serum and tissue from patients with neoplasms, particularly yolk sac tumors and hepatocellular carcinomas.

The presence and distribution of AFP in cytology aspirates from the liver were studied in 15 cases with hepatocellular carcinoma, one with liver cirrhosis, 3 of fetus, 2 of normal control and one with teratoma using the peroxidase-anti-peroxidase method (PAP). AFP-PAP method also was applied to tissue sections in each case for comparison.

Out of 15 cases with hepatocellular carcinoma, 11 were positive for AFP in both cytological and histological specimens. Three cases were negative for AFP and one was negative for AFP in cytological specimen although the histological specimen was positive.

An attempt was made to grade all the hepatocellular carcinomas using as a basis Edmondson's classification of histology, modified for applicability to cytological diagnosis. It was classified into four degrees of grading, according to (1) the N/C ratio, (2) size and degree of hyperchromatism of the nuclei, (3) quantity, granularity and acidophilic quality of the cytoplasm and (4) cohesive quality of tumor cells.

The degree of grading was parallel in both histological and cytological specimens. There was some correlation between the level of serum AFP and the degree of grading in cytology for all hepatocellular carcinomas.

Our preliminary results indicate that immunocytochemistry using AFP is helpful in cytodiagnosis of primary hepatocellular carcinomas.

\section{文献}

1) Johansen, P. and Svendsen, K.N. : Scan-guided fine needle aspiration biopsy in malignant hepatic disease, Acta Cytol., 22:292 296, 1978.

2）川生 明, 稻葉義己 : 酵素抗体法の細胞診への導入, 臨床 
病理 (特集), $41: 33 \sim 44,1981$.

3）松尾 武-他: 原発性肝癌の細胞診, 日臨細胞誌, 20 : $56 \sim 63,1981$.

4）武藤邦彦・他 : 腹部腫瘍（主として肝, 胆, 膵）の超音波 透導下穿刺吸引細胞診, 日臨細胞誌, $20: 657 \sim 669,1981$.

5）日本肝癌研究会編: 原発性肝癌取扱い規約, pp. 28 , 金 原出版, 東京, 1983.

6）及川正道・他 : 肝穿刺細胞診一細胞診と最終診断の不一致 例の検討を中心として一, 日臨細胞誌，23:563 570, 1984.

7）長村義之 - 他 : 酵素抗体法の細胞診への灾用一光顕, 電顕 用染色手技確立と体腔液細胞診への応用一, 病理と臨床, $12: 1713 \sim 1719,1983$.

8) Schwerk, W.B., et al. : Ultrasonically guided fine needle biopsies in neoplastic liver disease: Cytohistologic diagnoses and echo pattern of lesions, Can- cer, $48: 1469 \sim 1477,1981$.

9）椎名義雄・他：細胞診における酵素抗体法応用に関寸る基 礎的研究, 日臨細胞誌, $21: 8 \sim 14,1982$.

10）椎名義雄 - 他 : 細胞診一の酵素抗体法の応用一酵素抗体閒 接法における pronase 消化効果一, 日臨細胞誌, 22 ： 218 227, 1983.

11) Verma, K. and Bhargava, D.K. : Cytologic examination as an adjunct to laparoscopsy and guided biopsy in the diagnosis of hepatic and gall bladder neoplasia, Acta Cytol., $26: 311 \sim 316,1982$.

12）山本玲子・他：超音波映像下経皮的肝穿刺による肝腫瘍の 細胞診ならびに組織診, 日臨細胞誌, $22: 182 \sim 191,1983$.

13）山本玲子・他：超音波映像下穿刺法による肝細胞癌の細胞 診一特に細胞配列および PAS 染色所見について一，日臨 細胞誌, $23: 554 \sim 562,1984$.

\section{図の説明}

写真 1 肝細胞癌, 細胞 Grade I (Pap. 染色, $\times 1,000$ )

写真 2 肝細胞癌, 細胞 Grade II (Pap. 染色, $\times 1,000)$

写真 3 肝細胞癌, 細胞 Grade III (Pap. 染色, $\times 1,000$ )

写真 4 肝細胞癌, 細胞 Grade III (Pap. 染色, $\times 1,000$ ), 多核巨細胞を混じる

写真 5 肝細胞癌, 細胞 Grade IV (Pap. 染色, $\times 1,000$ )

写真 65 力月ヒト胎児肝, AFP 陽性. a : 組織標本 (AFP-PAP 法, $\times 200$ )。 b : 細胞標本 (AFP-PAP 法, $\times 400)$

写真 7 肝細胞癌 (手術症例 1), 組織標本 Grade II carcinoma. a : H-E 染色, $\times 400$. b : AFP-PAP 法陰性, $\times 200$

写真 8 肝細胞癌 (手術症例 1), 細胞標本, 細胞 Grade II. a : Pap. 染色, $\times 1,000$. $\mathrm{b}$ : AFP-PAP 法陰性, $\times 800$

写真 9 肝細胞癌 (手術症例 3), 組織標本 Grade III carcinoma. a : H-E 染色, $\times 400$. b : AFP-PAP 法陽性, $\times 400$

写真 10 肝細胞癌 (手術症例 3 ), 細胞標本, 細胞 Grade IV. a : Pap. 染色, $\times 800$. b : AFP-PAP 法陽性, $\times 1,000$

写真 11 肝細胞癌 (手術症例 4 ), 組織標本 Grade II carcinoma. a : H-E 染色, $\times 400$. b : AFP-PAP 法陽性, $\times 400$

写真 12 肝細胞癌 (手術症例 4 ), 細胞標本, 細胞 Grade III. a : Pap. 染色, $\times 800$. b : AFP-PAP 法陽性, $\times 800$

写真 13 肝細胞癌 (剖検例 5 ), 組織標本 Grade IV carcinoma. a : H-E 染色, $\times 400$. b : AFP-PAP 法陽性, $\times 200$

写真 14 肝細胞癌 (剖検例 5 ), 細胞標本, 細胞 Grade III IV. a : Pap. 染色, $\times 800$. b : AFP-PAP 法陽性, $\times 1,000$ 


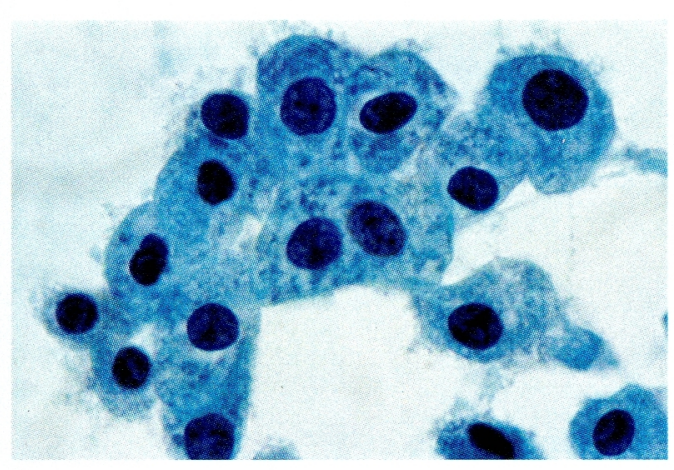

写真 1

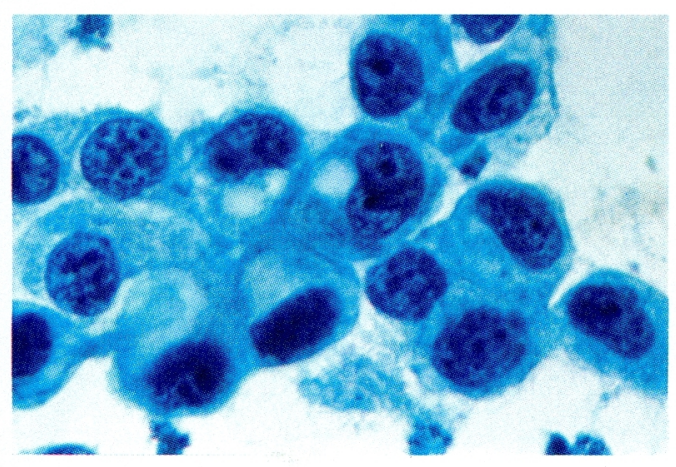

写真 2

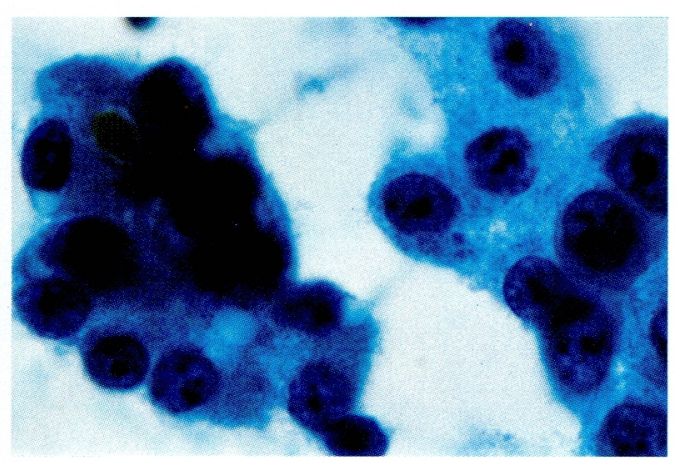

写真 3

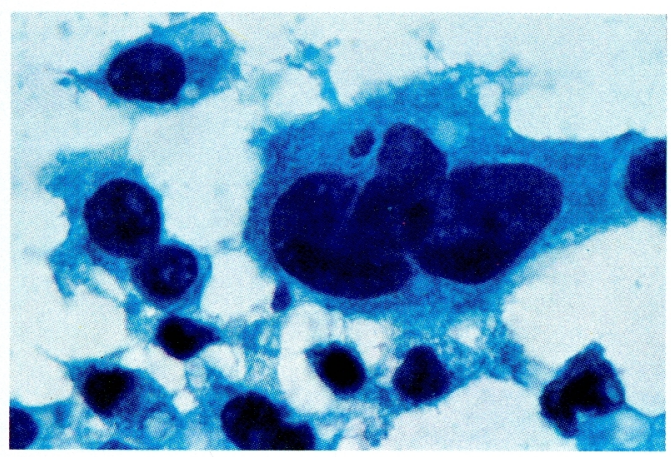

写真 4

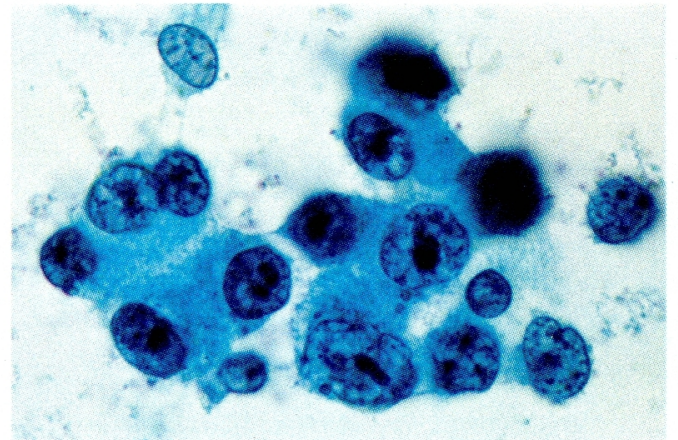

写真 5

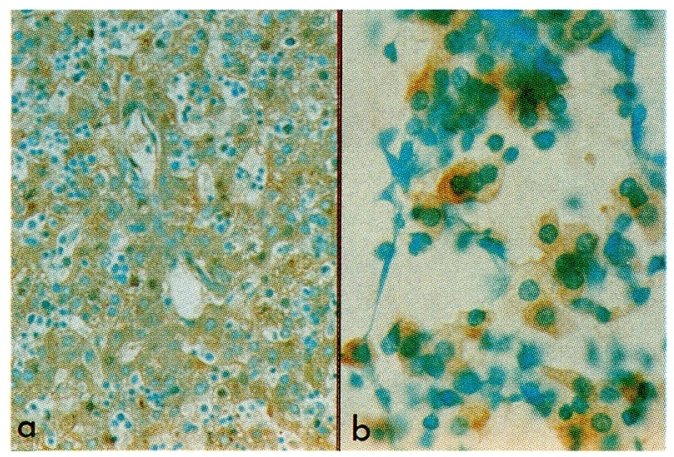

写真 6

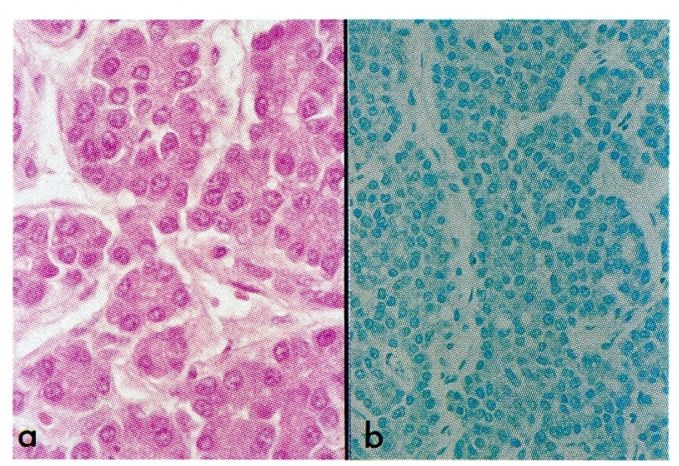

写真 7

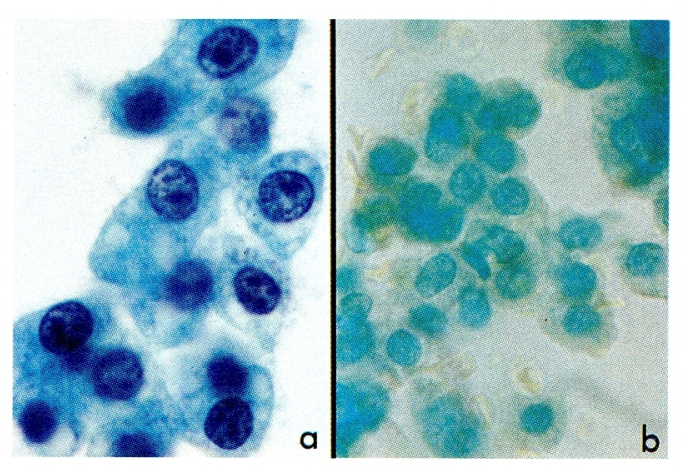

写真 8 


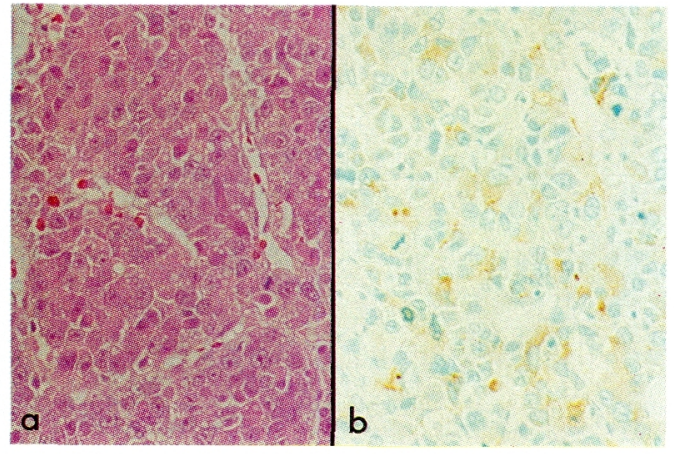

写真 9
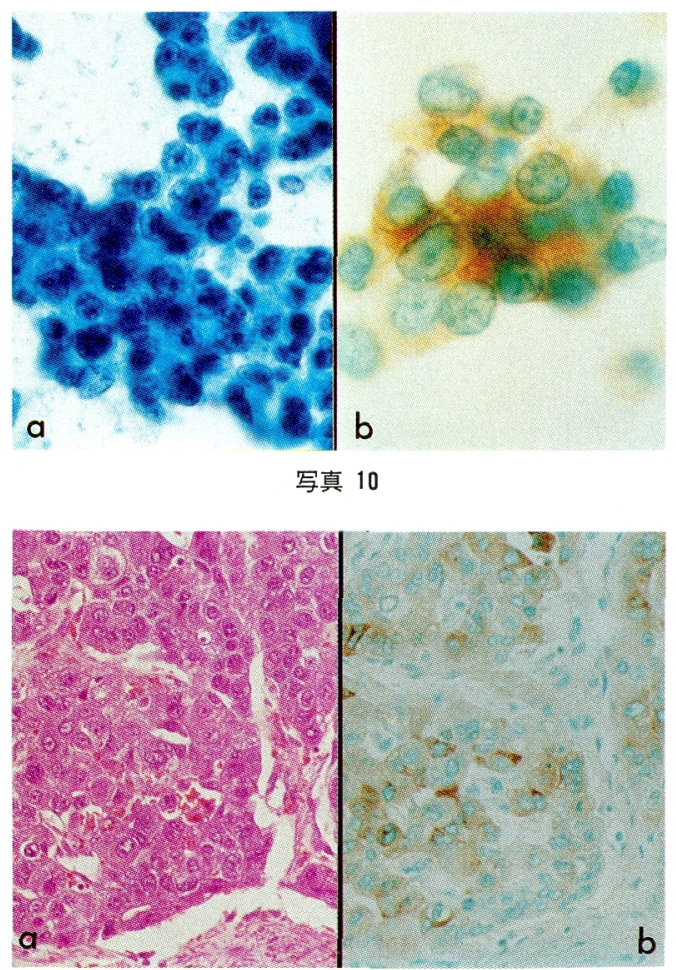

写真 11

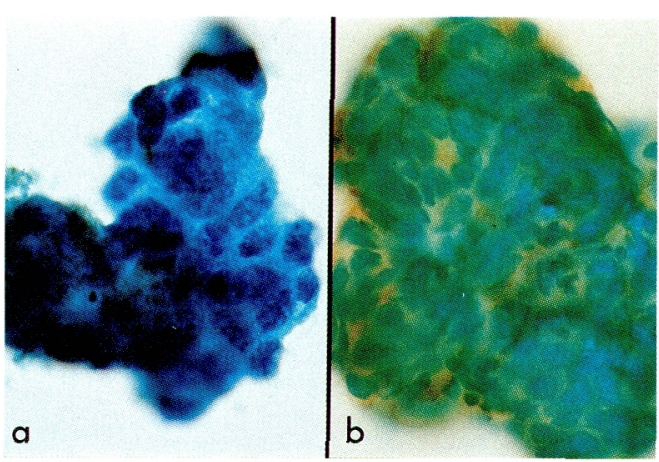

写真 12

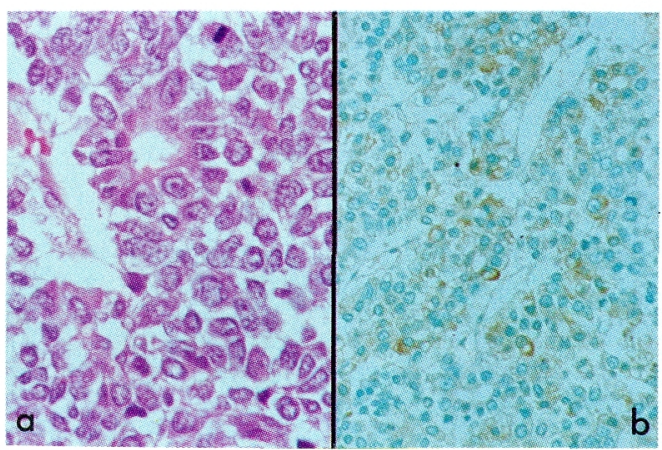

写真 13

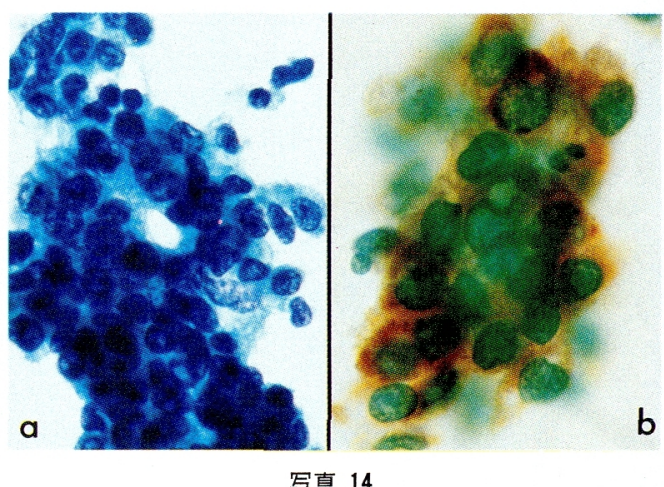

